\title{
Current trends in the financing of the innovative component in the agricultural sector
}

\author{
Aleksey V. Mikryukov, and Anna I. Serebrennikova \\ Ural State University of Economics, 620144 Ekaterinburg, Russia, 620114
}

\begin{abstract}
The article analyzes the issues of financing the innovative component in the agribusiness of Russia. The article brings the analysis of the main indicators of agricultural production and reveals the current state of development of the agricultural sector. The authors highlight the features of the innovation process in the agricultural sector and the main directions of innovation in the activities of agricultural enterprises. The article also analyzes the main indicators of innovative activity in agriculture for the period 2016-2019. The work describes the sources of financing of innovation activities and the structure of institutions to support the innovation component in the agribusiness. The authors proved that the banking system is reluctant to lend to agricultural enterprises, and only a few Russian banks finance innovative developments in the agricultural sector. It is concluded that for the successful development of the agroindustrial complex, it is necessary to introduce innovations in production technologies, which requires increasing investment, as well as strengthening state support for the industry.
\end{abstract}

\section{Introduction}

The agribusiness of Russia is one of the priority parts of the economy. By its significance and uniqueness, it is the main component of industrial development, occupying a special niche in the structure of the national economy, the effective development of which is of important economic, economic and social significance for the state [12]. Significant organizational, economic and social changes in the country, the transition to digital innovation development, involve the widespread use of new activities and innovative technologies, including in agro-industrial production. The importance of innovation processes in the agribusiness is primarily due to globalization and large-scale market changes in the world market, which entail an increasing role of competition, in which it is innovation and innovative technologies that are an effective way to combat competition, as they lead to lower production costs, increasing volumes and improving the efficiency of agricultural production [2]. In this regard, the study of problematic issues of the innovative component of the domestic agribusiness and its financing is being updated.

\section{Materials and methods}


The methodological basis of the study was a review of the works of domestic and foreign scientists on improving efficiency in the agricultural sector, based on investments aimed at implementing innovations. The main provisions of structural and situational analysis with the use of statistical methods of data processing were used in the research

\section{Results and discussion}

Implementation of government reform measures in almost all sectors of the economy, has ensured sustainable development in agribusiness. In particular, the implementation of measures on import substitution had a positive impact on the primary sector of agriculture. Over the past nine years (2010-2019), the increase in agricultural production in 2019 amounted to almost $50 \%$ (figure 1), including an increase in crop production of more than $60 \%$, in livestock - $45 \%$ (figure 2 ).

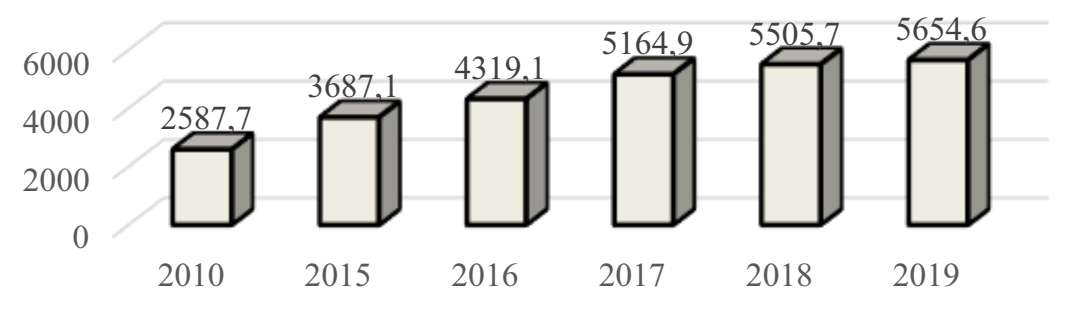

Fig. 1. Dynamics of agricultural production in 2010-2019 (billion rubles) ${ }^{1}$

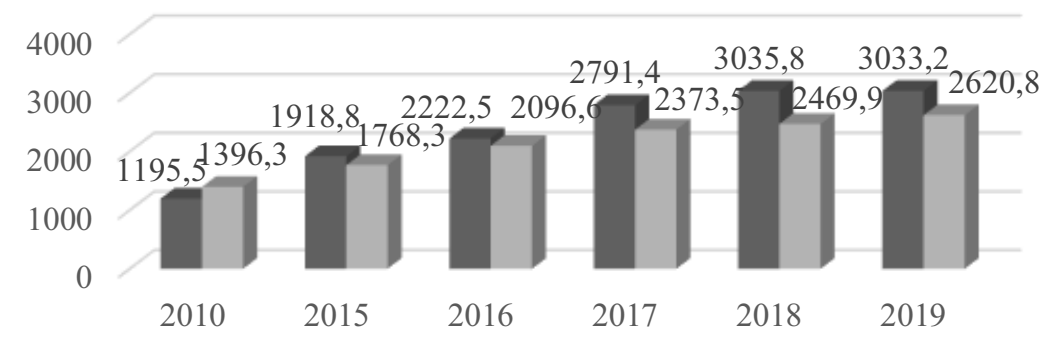

Fig. 2. Dynamics of livestock and crop production in 2010-2019 (billion rubles) ${ }^{1}$

However, the increase in production did not bring additional profit to agricultural organizations. According to the Ministry of agriculture, in 2019, the profitability of agricultural organizations (including subsidies) was $14.6 \%$ instead of $15 \%$, but according to updated data from Rosstat, the net financial result of agricultural organizations in 2019 was only $87.5 \%$ of the level of 2018 [5].This is primarily due to the deterioration of the main production facilities used by agricultural enterprises, as well as the lack of effective ways of technological renewal of production assets with the use of innovative production, management and organization technologies. And most importantly, there is no investment component, with which it is possible to update the fixed assets of the agribusiness.

A new model of economic development of the agribusiness is being formed in Russia. It assumes a transition from the strategy of import substitution to the stage of balanced

${ }^{1}$ Made by the authors using [14, 21] 
effective growth, aimed at increasing the level of availability of agricultural goods for the population, stimulating exports, improving the investment climate, increasing labor productivity based on the introduction of new technologies, rational organization and spatial management of production [1].

To solve the tasks set to create a high-performance export-oriented agricultural sector, it is necessary to implement an innovative model for the development of the industry and a steady flow of effective innovations into agricultural production $[12,13]$. The specifics of the innovation process in agricultural production are shown in figure 3.

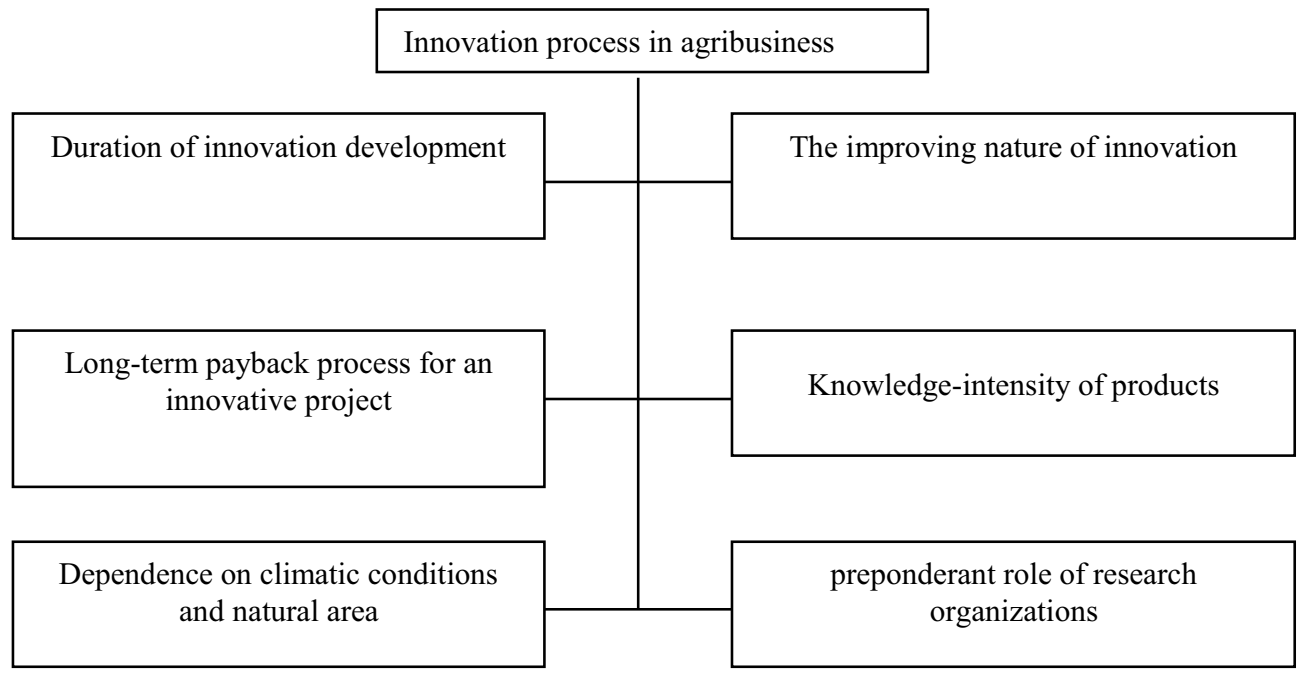

Figure 3. Specifics of the innovation process in agricultural production ${ }^{2}$

As we can see from figure 3 , the innovation process in the agricultural sector is characterized by a number of specific features. The innovation process in the agribusiness is primarily dependent on climatic territorial conditions, and this applies both to the costs of innovative technologies and the timing of the implementation of an innovative project, which indicates the risk of investment in these projects. However, the duration of development and implementation of innovations makes it possible to use effectively the human resources of both research institutes and agribusiness enterprises. In General, we can identify three main areas of innovation in the activities of agricultural enterprises (figure 4)



${ }^{2}$ Made by the authors using [22] 
Figure 4. The main directions of innovation implementation in the activities of agricultural enterprises $^{3}$

Organizations that ensure the functioning of the agricultural innovation system within the framework of the national innovation system (NIS) of the agribusiness should include [1]:

- Supporting organizations: financial and banking system; transport and marketing infrastructure; professional networks, including: associations of agricultural producers (farmers ' associations), associations in the processing industry and trade; system of education.

- Research organizations as producers of mainly codified (explicit) knowledge in the field of agricultural innovation: national, foreign and international, public and private agricultural research organizations; universities, institutes, specialized secondary and vocational colleges (public and private); research foundations (public and private).

- Research divisions within private companies and non-governmental organizations, sometimes producing codified knowledge in the field of agricultural innovation. 3

- Corporate organization system of agribusiness as recipients and users of codified knowledge, manufacturers of agricultural machinery and equipment, mineral fertilizers and pesticides, etc., as well as agro-processing; organizations of wholesale and retail trade in the markets of agricultural raw materials and food; commodity traders in the markets of means of production for agriculture; transport organizations and private cargo carriers.

- Consumers of agricultural products: consumers of food and foodstuffs in cities and rural areas; industrial consumers of agricultural raw materials.

- State institutions responsible for the development and implementation of agricultural policy as producers of mainly codified knowledge in the field of agricultural innovation.

- Intermediary organizations: non-governmental organizations; governmental organizations providing advisory services in the field of agriculture; private organizations providing advisory services in the field of agriculture.

However, cyclical economic crises and prolonged sanctions caused mainly by political processes reduce the innovation and investment activity of agricultural enterprises. According to both Russian and foreign scientific farmers, innovation is the best way out of the current global financial and economic crisis [16]. This thesis finds its practical confirmation in the following global trends:

- implementation of state programs aimed at maintaining, developing and stimulating the innovation sphere (contracts, subsidies, benefits and compensation), as well as research activities and training of scientific personnel;

- development institutions (both national and supranational) create a favorable climate for the development and implementation of innovations, innovative elevators are formed;

- companies are actively implementing innovations in production, management and other processes; they are reviewing the structure of expenditures - from year to year, an increasing share of budgets is allocated to R\&D activities;

- new financing tools are emerging that meet the requirements, risks, and specifics of innovative projects and innovative-active companies.

Global trends indicate that the share of innovative companies in many sectors already reaches $10-20 \%$ and will grow rapidly in the coming years [10; p. 3]. In turn, the innovative activity of Russian farmers according to analytical studies varies from $3.9 \%$ to $4.2 \%$ as of 01.01.2019, in 2017 it was 3.7\% [6] (table 1).

\footnotetext{
${ }^{3}$ Made by the authors using [22]
} 
Table 1. Key indicators of innovation activity in agriculture in 2017-20194

\begin{tabular}{|l|l|l|l|}
\hline Indicators & $\begin{array}{l}\text { On } \\
01.01 .20 \\
17\end{array}$ & $\begin{array}{l}\text { On } \\
01.01 .20 \\
18\end{array}$ & $\begin{array}{l}\text { On } \\
01.01 .20 \\
19\end{array}$ \\
\hline $\begin{array}{l}\text { Share of organizations that implemented technological } \\
\text { innovations in agriculture, in the total number of } \\
\text { organizations, \% }\end{array}$ & 3,4 & 3,1 & 3,4 \\
\hline $\begin{array}{l}\text { Volume of innovative goods, works, and services in } \\
\text { agriculture, mln rubles. }\end{array}$ & 22222,9 & 28446,0 & 33829.1 \\
\hline $\begin{array}{l}\text { Share of innovative goods, works, and services in the total } \\
\text { volume of goods shipped, work performed, and services, \% }\end{array}$ & 1,4 & 1,8 & 2,1 \\
\hline $\begin{array}{l}\text { Expenditures on technological innovations in agriculture, mln } \\
\text { rubles }\end{array}$ & 14963.3 & 15806.0 & 21960.5 \\
\hline $\begin{array}{l}\text { The share of expenditures on technological innovations in the } \\
\text { total volume of goods shipped, work performed, and services, } \\
\%\end{array}$ & 4,3 & 3,7 & 3,5 \\
\hline
\end{tabular}

Therefore, in Russia, confidence in innovation, much less in investment in agricultural innovations, arises only after testing by Western colleagues. As an example, we can cite the project of a new technology for" pasteurization " of milk, developed by D. Urvachev back in 2010, but investments for the project were found only in 2016. The project of creating small closed ecosystems-aquariums that use natural waste of fish for growing plants, in turn, purifying water, developed by A. Militsin and E. Voitenkov, found understanding from the American company BacktotheRoots (today the new company employs 6 people, monthly income exceeds 4 million rubles).It is also possible to distinguish the project " Izbenka" developed by A. Krivenko; the project for raising sheep by A. Prokhorov; rural startup of S. Koryukin in the Kurgan region-a livestock farm that has grown into the agricultural firm "Russian field"; the initiative of the Istomin family "Zoprotein" - the use of fly larvae for the production of feed protein and processing of food waste (they obtain biomass much faster than competitors)[8].

These innovative projects were implemented mainly at their own expense. And the ISSEK NRU HSE confirms this trend by the analytical data. According to these data, the share of own funds accounts for $52.1 \%$ in 2018 , the share of attracted funds is $47.9 \%$, of which the budget funds are only $2.2 \%$ (figure 5 ). For comparison, the EU budget expenditures on the Common agricultural policy in 2018 amounted to 58.6 billion euros, including direct payments to farmers-41.5 billion euros, expenditures related to market measures-2.7 billion euros, and expenditures on agricultural development-14.3 billion euros. [3]. The largest amount of support from the EU budget, according to the ESP, was received by agriculture in France ( 9.5 billion euros), Spain (6.8 billion euros), Germany (6.4 billion euros), Italy (5.8 billion euros), Poland (4.6 billion euros), great Britain (3.9 billion euros), Romania ( 3 billion euros). Given that there are about 10 million farms in the EU, state support (subsidies) for one farm is about 6 thousand EUR per year. [23]

\footnotetext{
${ }^{4}$ Made by the authors using [6, 7]
} 


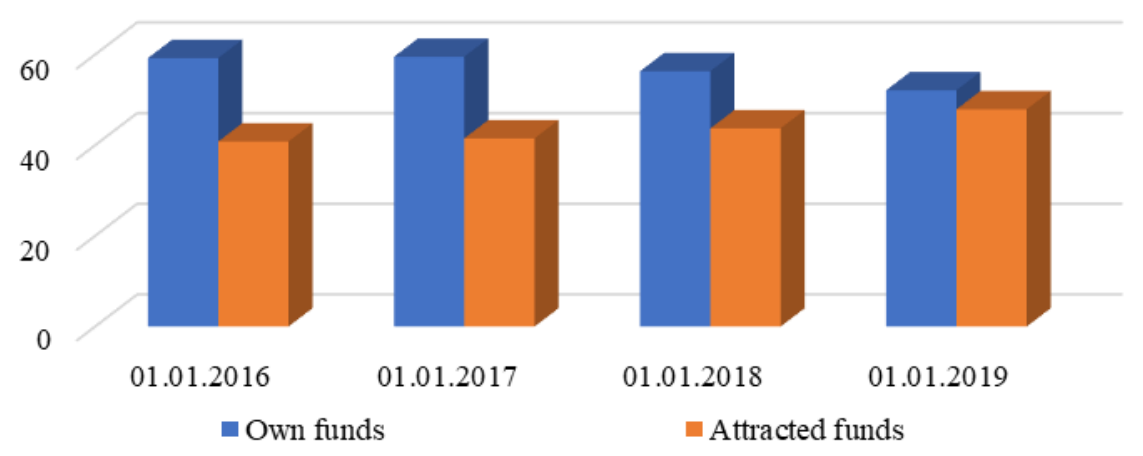

Figure 5. Sources of financing of innovation activities in the agribusiness $(2019)^{5}$

However, it is worth noting that for innovative development and investment activity of agricultural production "State program on development of agriculture for the period 2013$2020 "$ is implemented, prolonged until 2025 [3]. This program is now giving positive results and strengthening the economic component of the country in general and agriculture in particular. But at the same time, the production of agro-industrial products still remains a subsidized sphere, as in many other developed foreign countries. The amount of state funding of the Russian Federation for agriculture in 2015-2019 is shown in table 2.

Table 2. Volume of state financing of the Russian Federation for agriculture in 2015-2019. ${ }^{6}$

\begin{tabular}{|l|l|l|l|l|l|}
\hline Indicators & 2015 & 2016 & 2017 & 2018 & 2019 \\
\hline $\begin{array}{l}\text { Expenditures from the consolidated budget of } \\
\text { the Russian Federation, bln rubles }\end{array}$ & 362,4 & 331,7 & 343,8 & 365,8 & 434,9 \\
\hline including from the Federal budget, bln rubles. & 208,2 & 03,1 & 214,1 & 225,7 & 288,8 \\
\hline $\begin{array}{l}\text { Expenditures from the consolidated budget, as } \\
\text { a\% of GDP, bln rubles. }\end{array}$ & 0,43 & 0,39 & 0,37 & 0,38 & 0,40 \\
\hline
\end{tabular}

As we can see from the presented data, the share of expenditures from the Federal budget increased from $57.3 \%$ in 2015 to $66.4 \%$ in 2019 [14], from regional budgets, the growth of expenditures in 2019 was $4.3 \%$ compared to 20018 . These indicators show that the state is focused on achieving consistency of structural changes in regional agri-food systems for priority provision of all-Russian development parameters. However, the growth of regional financing occurred while the aggregate surplus of regional budgets declined in 2019 (4.7 billion rubles against 0.5 billion rubles in 2018) [5].

It is also worth paying attention to the poor quality of management in the implementation of targeted state programs in the agribusiness. Thus, the Court of Auditors of the Russian Federation points to the need to increase the transparency of state support, including ensuring equal access to subsidies and loans on concessional terms for various categories of agricultural producers [5]. Today, only a limited number of recipients can benefit from state support in the form of subsidies and benefits at the regional level. For example, in the Rostov region in 2017-2018, from 60 to $100 \%$ of 8 types of subsidies were received by one to three agricultural producers; in the Saratov region in 2018, there were 1.5 thousand of them, and in 2019 there were 700 . Fewer and fewer farmers are applying

\footnotetext{
${ }^{5}$ Made by the authors using [21]

${ }^{6}$ Made by the authors using [5, 14, 21]
} 
for state support, considering the requirements for its provision excessive, and checks strict [7].

In addition to state support, innovative agricultural projects in Russia are supported by several structures that make up the so-called "innovation elevator". Such structures include the SKOLKOVO Innovation center, the RUSNANO venture Fund, the Russian venture company (RVC), Vnesheconombank, and the SME Corporation [4]. Support for innovation activities provided by the "innovation elevator" institutes is shown in table 3.

Table 3. Support for innovation provided by the "innovative elevator» institutions ${ }^{7}$

\begin{tabular}{|c|c|c|c|}
\hline Stage & Institution & \multicolumn{2}{|l|}{ Measures of Support } \\
\hline $\begin{array}{l}\text { Before } \\
\text { planting }\end{array}$ & $\begin{array}{l}\text { Fund for development of } \\
\text { small enterprises in } \\
\text { science and technology }\end{array}$ & $\mathrm{R} \& \mathrm{D}$ funding & $\begin{array}{l}\text { Grant up to } 500,000 \\
\text { rubles }\end{array}$ \\
\hline \multirow{2}{*}{ Planting } & RBC Group & $\begin{array}{l}\text { Participation in the } \\
\text { authorized capital }\end{array}$ & $\begin{array}{l}\text { Up to } 50 \% \text { of the } \\
\text { authorized capital (but no } \\
\text { more than } 300 \text { million } \\
\text { rubles) }\end{array}$ \\
\hline & $\begin{array}{l}\text { Fund for development of } \\
\text { small enterprises in } \\
\text { science and technology }\end{array}$ & $\begin{array}{l}\text { Providing funds for } \mathrm{R} \\
\& \mathrm{D}\end{array}$ & Grant up to $5 \mathrm{mln}$ rubles \\
\hline \multirow[b]{3}{*}{ Sturtup } & RBC Group & \multirow{2}{*}{$\begin{array}{l}\text { Providing venture } \\
\text { capital investments }\end{array}$} & \multirow{2}{*}{$\begin{array}{l}\text { Up to } 50 \% \text { of the } \\
\text { investments sum }\end{array}$} \\
\hline & JSC «RUSNANO» & & \\
\hline & SME Corporation & $\begin{array}{l}\text { Provision of subsidized } \\
\text { loans and guarantees }\end{array}$ & $\begin{array}{l}\text { Guarantees up to } 70 \% \text { of } \\
\text { the obligation amounts; } \\
\text { loans at } 10.6 \% \text { for a } \\
\text { period of up to } 3 \text { years, } \\
\text { the maximum loan } \\
\text { amount is } 1 \text { bln rubles }\end{array}$ \\
\hline \multirow{2}{*}{$\begin{array}{l}\text { Expansion } \\
\text { and } \\
\text { growth } \\
\text { stage }\end{array}$} & Vnesheconombank & $\begin{array}{l}\text { Provision of loans and } \\
\text { guarantees }\end{array}$ & \\
\hline & JSC «RUSNANO» & $\begin{array}{l}\text { Participation in the } \\
\text { capital of project } \\
\text { companies, loans and } \\
\text { guarantee support }\end{array}$ & $\begin{array}{l}\text { Up to } 50 \% \text { of the } \\
\text { authorized capital }\end{array}$ \\
\hline
\end{tabular}

Unfortunately, the banking system is reluctant to lend to the agricultural industry. Only a few Russian banks finance innovative developments in the agricultural sector. The active policy in short-term agricultural lending is taken by JSC "Rosselkhozbank", its share is $66.7 \%$, the share of PJSC "Sberbank" is $17.2 \%$, Vnesheconombank-8.1\%, SME Bank$5.3 \%$, JSC "Alfa-Bank" - 2.7\% (figure 6).

\footnotetext{
${ }^{7}$ Made by the authors using $[4,15,17,18,19,20]$
} 


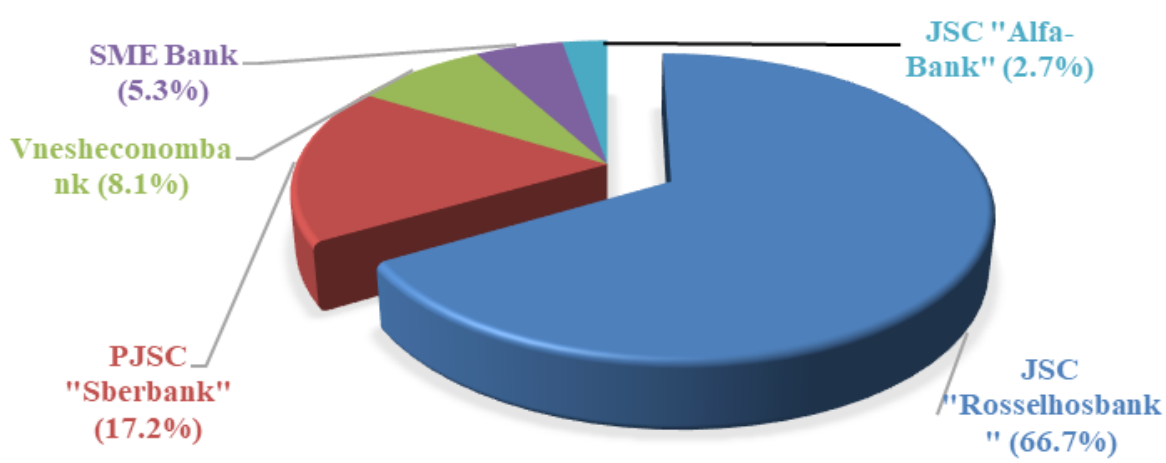

Fig. 6. Share of Russian banks involved in financing innovative projects in agribusiness in $2019^{8}$

For example, Rosselhosbank supports actively innovative technologies and new effective solutions for agricultural enterprises. The Bank is a key source of concessional finance. This Bank was the first to submit a register of potential borrowers to the Ministry of agriculture of the Russian Federation in 2020. SME Bank (a subsidiary of SME Corporation) lended 50 million rubles for a project to create a digital innovative agricultural holding in Buryatia. The loan was granted at a rate of 5\% per annum for six years within the concessional lending program of the Ministry of agriculture of the Russian Federation (Resolution No. 1528). The loan is secured by a guarantee from the SME Corporation. The Guarantee Fund of the Republic of Buryatia acted as a guarantor. Buyan company will create an innovative agricultural holding with a full production cycle, from crop production to animal husbandry, meat processing and its subsequent sale, on the basis of an existing enterprise in Buryatia. As part of the project, the company plans to introduce satellite navigation systems, as well as electronic identification of livestock. The issued funds will be used to increase the number of cattle to 4.7 thousand heads [11].

When planning their innovative activities, domestic agribusiness enterprises face a number of problems: first, the lack of own funds and the lack of a stable source of their inflow due to a high share of accounts payable; second, the lack of an effective system for regulating prices for semi-finished products and finished products; third, with high interest rates on Bank credit products for farmers in the country. To eliminate these problems, it is necessary to develop a comprehensive program to stimulate investment activities of agroindustrial enterprises of the Russian Federation. Without its participation, it is impossible to increase the innovative activity of domestic enterprises that feel a lack of resources. It is the lack of active support for innovation in the agro-industrial sector from the state that causes the low growth rates of the domestic agribusiness as a whole.

State support for agricultural enterprises can make a significant contribution to the development of the Russian agricultural sector. In this regard, the state policy should be aimed at the development and implementation of appropriate mechanisms and tools to stimulate innovative activity of agricultural enterprises. It is possible to stimulate the development of innovative activities of agricultural enterprises through direct state influence (distribution of budget and extra-budgetary funds); indirect state influence (development of financial leasing, scientific activities, market infrastructure, protection of intellectual property rights, tax benefits, etc.).

\footnotetext{
${ }^{8}$ Calculated by the authors using $[4,12,15,17]$
} 


\section{Conclusions}

Thus, the analysis showed that in recent years there has been an increase in production in the agricultural sector, which has a positive impact on the economy of the state, as well as the life of the population. The level of competitiveness of production of agricultural enterprises is increasing. At the same time, the profit of agricultural enterprises is growing insignificantly. Agricultural enterprises face a lack of investment from various financial institutions, despite their investment attractiveness.

Innovative development of organizational and production processes of agricultural enterprises is necessary. Currently, there are many problems hindering the development of agriculture, among which the most important is the lack of active support of innovation activities in agribusiness by the state. This reduces the growth rate of the domestic agricultural sector as a whole. The introduction and support of innovations is the only possible way out of the current global financial and economic crisis, where the state should play a significant role. Sustainable balanced innovative development of agricultural enterprises is an important prerequisite for improving not only economic growth but also social level of life of people. It also has major economic and social importance to the state.

\section{References}

1. A. I. Trubilin, The agrarian economy of Russia: problems and development vectors, 342, (2018)

2. Agricultural review of March 16 2018, (2018) http://www.agroinform.ru/index.php/novosti/agroobzor/5437-agroobzor-ot-16-marta-2018-goda-46

3. The state program for the development of agriculture and regulation of agricultural products, raw materials and food markets for 2013-2020, (2020)

4. State development institutions and support programs. http://viperson.ru/articles/gosudarstvennye-instituty-razvitiya-i-programmy-podderzhki

5. Report on the implementation in 2019 of the Action Plan of the Ministry of Agriculture of the Russian Federation for 2019-2024. http://mcx.ru/upload/iblock/fed/fed4bf5f2dbf9ed1fd20ac03fe212373.pdf.

6. Dynamics of costs and results of innovations in Russia, 2019. https://issek.hse.ru/data/2019/10/09/1527914545/NTI_N_147_09102019.pdf

7. L. M. Gokhberg, Indicators of innovation, 376 (2019)

8. Innovations in agriculture. https://obizneseok.ru/innovacii-v-selskom-xozyajstve.html

9. Innovation activities of agricultural organizations Issek.hse.ru, https: //issek.hse.ru/news/209489796.html.

10. T.E. Marinchenko, V.N. Kuzmin, A.P. Korolkova, A.V. Goryacheva, The results of innovation and scientific and technological development of agriculture, 232 (2019)

11. Bank will finance the creation of an innovative agricultural holding in Buryatia. https://tass.ru/msp/8029109

12. A.V. Mikryukov, A.I. Serebrennikova, Yu.V. Kuvaeva, Improving approaches to financing innovative agricultural projects, 273 (2017)

13. V.I. Nechaev, P.V. Mikhaylushkin, Agricultural Economics of Russia, 5, 52 (2019)

14. Overview of the agricultural market $\quad 2019$. https://ru.investinrussia.com/data/file/obzor-rynka-selskogo-hozyajstva-2019.pdf 
15. On the participation of Rosselkhozbank JSC in lending to the agricultural sector and supporting the integrated development of rural areas, 2019. http://komitet220.km.duma.gov.ru/

16. S.B. Ognivtsev, Int. Agric., 2, 77 (2019)

17. The official website of Vnesheconombank. https: //web.rf

18. The official website of RVC OJSC. http: //www.rvc.rg

19. The official website of the Industrial Development Fund. http://www.frprf.ru

20. The official website of the Foundation for the Promotion of the Development of Small Forms of Enterprises in the Scientific and Technical Field. http://fasie.ru

21. Rosstat, Agriculture in Russia: 2019, 91 (2019)

22. N.N. Sologub, Innovations in agriculture: problems and prospects, 6, 72 (2018)

23. V. Sushko, Agrarian economy, 2, 12 (2020) 